UDC 321.01:316.485.6: $316(075.8): 316.613 .434$

DOI: https://doi.org/10.21564/2075-7190.47.218963

Kozlovets Mykola Adamovych, Doctor of Philosophical Sciences, Professor, Professor of the Department of Philosophy and Political Science, Ivan Franko Zhytomir State University, Ukraine e-mail: mykola.kozlovets@ukr.net ORCID ID: 0000-0002-5242-912X

Slyusar Vadym Mykolayovych, Doctor of Philosophical Sciences, Associate Professor, Associate Professor of the Department of Philosophy and Political Science, Ivan Franko Zhytomir State University, Ukraine e-mail:vadmyks1@gmail.com

ORCID ID: 0000-0002-5593-0622

\title{
PRIVATIZED VIOLENCE: THE ESSENCE AND TYPES OF ITS IMPLEMENTATION IN MODERN WORLD
}

The social nature of violence and its forms, peculiarities of manifestation and realization are considered in the article. The concept of "privatized violence» was conceptualized in the context of theoretical and general cultural studies of violence, which made it possible to distinguish it from the general conceptual term «social violence» and to define it as an objective factor of social development, as well as to organize it on various grounds. The reasons for the occurrence of privatized violence and the factors that cause it to intensify in the current context. On the basis of the historical experience analysis and modern practice, the content and specifics of the privatized violence manifestation, mechanisms and factors of its implementation in the modern world are investigated. Particular attention is paid to the impact of globalization processes on violence, the establishment and strengthening of its indirect, privatized forms. The manifestations of violence and aggression state the importance of biological and psychological qualities, but the determining factor is the social factor. The peculiarity of different approaches to the problem of privatized violence is the search for tools, a certain theoretical model that will exclude or regulate the manifestations of this social phenomenon at all levels of human practices. Analysis of the anthropological determinants of human aggressiveness shows that centuries of socio-genesis, a person's internal ability to contain his tendency to violence and aggression, is easily overcome by the influence of external factors, such as ideology. In addition, the sphere of human corporeality is now increasingly regulated through medicine, psychology, genetics, educational and manipulative technologies. If political violence is institutionalized, incorporated into the mechanism of action of society's values, embedded in the social structure by various methods, and transformed into an instrument of social order organization, 
primarily through coercion, stimulation and persuasion, then hidden violence, on the contrary, stimulates the increase of uncertainty and chaotic life of everyday life.

The anthropological component of privatized violence turns it into a phenomenon of social consciousness, which is an essential factor determining the process of cultural and historical society development. The function of punishment exercised by the subjects of privatized violence to establish "social justice» is the modern equivalent of the institute of vengeance, which is based on a specific irrational understanding of people's perceptions of damages through revenge. The peculiarities of the political culture of transformational Ukrainian society are revealed, which influence the intensification of socio-political tensions and motivation for privatized forms of violence. Social groups that resort to privatized violence and models of communicative behavior and management styles in conflict and post-conflict situations are considered. The conclusion is made about the social conditionality of privatized violence and the feasibility of forming a culture of nonviolence, tolerance and consent in the current context.

Keywords: violence, non-violence, phenomenology of violence, social violence, privatized violence, fairer violence, society, social order.

Formulation of the problem. Violence is an integral part of social life throughout human history. Despite its changing forms and instrumental purpose (such as expression of an aggressive nature, means of survival and profit, seizure of territory or scarce resources, affirmation of "race purity", etc.), there has been no historical period devoid of violence. Western researchers D. North, J. J. Wallis, and B. R. Weingast attempted to conceptually interpret world history with a view to addressing the problem of violence in human societies through the introduction of different social orders, different belief systems, type of organizations, political and economic institutions. In their view, it is precisely how societies respond to the ever-present threat of violence that defines and structures forms of human interaction, including types of political and economic systems [1]. The legitimacy of the right of individuals or social groups to encroach on the health, freedom and other values of human life at all times has been extremely costly to humanity. However, today, in the age of rapid development of science, technology and technology, its price is extremely increasing, it can be exceptionally widespread in its destructive effects. Therefore, the problems of the impact of globalization processes on violence, in particular, the strengthening of indirect, privatized forms of it, are being actualized.

Analysis of recent research and publications. The problem of violence has always occupied an important place among the theoretical problems of scientific discourse. In contemporary scientific literature, the problem of violence is explored both in the subject field of political science (G. Agamben, F. von Hayek, K. Schlegel, A. Dmitriev, I. Zalysin, S. Kuzin), and in relation to the philosophical (J. Derrida, S. Zizek, M. Staudigl), psychological (F. Fanon), ethical (L. Svendsen), mass 
media (H. M. Enzensberger), cultural (W. Sofsky) and other scientific intelligence [2-18]. Researchers have analyzed structural violence in the context of social justice; justification of the state monopoly on violence and the use of specific means of social change; identification of various forms of violence with emphasis on the problem of the individual; comprehending the scale of violence [6, p. 24-26; 19].

Various conceptual interpretations of the problem of violence in the political aspect are found in the works of Ukrainian scholars V. Bebyk, D. Boyko, C. Holovaty, Ye. Holovakha, V. Horbatenko, M. Mykhalchenko, V. Kravchenko, V. Kremen, V. Ostroukhov, O. Panfilov, O. Poltorakov, O. Rudakevich, F. Rudych, V. Slyusar, V. Tkachenko, M. Trebin, V. Tselyuk, M. Shulga and others. [20-26]. At the same time, the problem of violence, primarily privatized, remains one of the most debatable, as the scientific approaches to addressing it differ significantly from one another. Thus, the scientific conceptualisation of this problem, which is connected with political analysis of the essence of violence in general, and privatized in particular, the content and types of its manifestation in the modern world, is actualized. Particularly in our time, the dismemberment, spread and outright simulation of man and the apocalyptic sentiment and all-pervasive cynicism-nihilism parasitizing on this media, the reverse side of which terror and terrorism both on the moral individual and political levels of the interstate stand. In addition, in domestic political science, studies of the problem of privatized violence are fragmentary, unsystematic. An analysis of work on issues of violence convinces us that this topic is vital for the future development and existence of humanity.

The purpose of the article is to investigate the causes of increased privatization of forms of violence, mechanism and factors of its implementation in the modern world.

Presenting main material. All societies, regardless of the principles of their organization, face the need to address the problem of the use of violence by individuals in the form of physical acts or threats to take such actions. Through violence, people and communities compete with one another for access to scarce resources or status. And people's actions are often of a «negative», destructive and destructive nature associated with violence and coercion; they are aimed, if not at the destruction, at the elimination of the enemy, to achieve a «victory» over him. Moreover, humanity cannot exist without resorting to violence against violence. The society generates and broadcasts a diverse background of ideas, some of which may be in demand in times of crisis in society. The most marginal concepts are channeled into dominant discourses when the deconstruction of traditional institutions occurs. The legitimation of violence is a mechanism of survival and protection that is realized by the collective unconscious. Almost the main sign of violent actions is a conscious violation of generally accepted norms, rules, agreements, which destroys established forms of communication, creates chaos. However, chaos is 
often interpreted as a transition to a «new» order. Violence can be carried out by the state and its bodies, by terrorist organizations or by individual groups and individuals using physical, political, economic, psychological, legal and other means.

Historical experience shows that violence, which in a number of cases can be justified (resistance to the aggressor, oppressors, etc.), in the end, always has a destructive nature, rejects society backwards, contributes to the demoralization and growth of the manifestation of the negative aspects of human nature. Widespread violent actions in today's society, with its technological and technical systems and capabilities, are particularly dangerous. It is only natural that society moves on to other technologies of social change on the basis of equality of the parties (of course, recognizing fundamental human rights), dialogue, compromise, solidarity, cultural and moral blocking of destructive tendencies of the person by means of internal, spiritual transformations, acceptance of personal own responsibility for evil. In doing so, one should see the particular danger of indirect psychological violence, which is expressed in the form of myths, distorted information, and manipulation of human consciousness.

Since ancient times, humanist thinkers have justified the right of the people to violence in cases of just wars, to fight tyranny. In accordance with these ideas, the constitutions of democratic states recognize the legal and moral right of the people to use force and fight against those who are trying to forcibly eliminate the democratic order. It should be noted that the understanding that violence produces only violence led to the formation in the 1920s of the ethics and practice of nonviolent struggle for a fairer society (L. Tolstoy, M. Gandhi, M. L. King) [27, p. 439].

Consequently, no society has been able to completely eliminate violence from people's lives, most of all - it has only been restrained or limited and directed. The instrument of such restraint, restriction and direction of disorderly violence is often organized violence by the state. Most of all, the violence was restrained or limited and directed. It is about using societies to control the political, economic, military, religious and educational activities of people and organizations with a view to mastering, limiting, deterring and consolidating violence. Actually, such models of social organization, in which relations between people and organizations, their access to scarce resources and means of violence, are structured and restricted by social institutions, are defined by D. North, J. J. Wallis, and B. R. Weingast as social orders [1]. The state uses the instrument of violence for the purpose of keeping within the social order and law the struggle of social groups or certain economic interests. In modern societies, violence is transformed into an instrument of social order organization, becoming a reliable and legitimate means of integrating and constructing power, population and territory.

It should be noted that at the turn of the XX and XXI centuries the institutional model of the evolution of the social order of $\mathrm{D}$. North drew the attention of 
Ukrainian social scientists. He developed the problem of social order as a problem of cooperation, which is solved by the institutions - the rules of the game in society or by human-made constraints that direct human interaction [28]. From this point of view, institutions structure the incentives of the subjects in the process of their economic, political and social interaction, directing human behavior in the direction desired for the social community. As a result, the uncertainty and chaos of everyday life decreases. Therefore, regulating the behavior of people in society by the criteria of proper and improper compliance with social regulations is accompanied by the use of both explicit and covert violence. Therefore, violence is a kind of institutionalization of social relations, whereby individuals or groups of people, through various means of external coercion and manipulation, subordinate themselves to the consciousness, will, ability, property and freedom of others.

One of the aspects of promoting new rationality as an attribute of violence in the age of globalization is its privatization and commercialization. The concepts of ("violence privatization» and "privatized violence») were widely used in the late 1990s in historical and political studies of terrorism, civil wars in Africa, drug trafficking in Latin America, and the most thorough theoretical understanding of the understanding of E. Eppler. It should be noted that the above concepts were, in Eppler's, primarily political and are ideologically left-wing. He defined privatized violence as a blending, on the one hand, of the fundamentalist fanaticism of the most egregious criminality, on the other. Therefore, it depends on the growth of inequality both within society and between societies [29, p. 12]

Privatized violence opposes the state, replaces it, denies the state monopoly on violence. The subject of private military formations, local armed formations of civil self-defense during the Civil War began to be addressed in the late 1990s. In particular, L. Martinez of the Civil War in Algeria: 1990-1998 described the emergence of armed forces in Algeria on different principles: regionally (as an armed wing of political parties), relative to the authorities (created to support the work of law enforcement), based on private interest (private armies) [30, p. 235]. It should be noted that the lack of permanent and sufficient consolidated political and legal control over the armed forces and technologies of destruction and violence, the existence of permanent organizations, independent of either the state or individuals, often leads to self-destruction and degradation of society. On the other hand, the declared instrument of the «right of nations to self-determination» was a legal instrument during the civil wars, on the basis of decolonization processes, despite the fact that its practical and political realization is, as a rule, against the background of a sharp and fundamental weakening of the state-political and social-political institutions in the former colonies [28, p. 131].

In general, it is possible to distinguish such groups that can own and execute privatized violence: private firms and organizations providing security, protection 
and security services, including «private armies«; organized crime groups that commit violence for profit; terrorists; militarized formations and protest groups that resort to violence in order to «declare themselves» or publicize their ideas, obstruct certain actions of the authorities [31, p. 46]. The classic context in which private agents of violence (or actors) can begin their ascent is the combination of political, economic, social and cultural prerequisites such as the functioning of a low-diversification dependent economy on primary commodity exports, social modernization without social development, and no conflict between traditions and the current norms, and the growing fear of identity loss, the considerable weakness of the state in fulfilling its essential functions, or, conversely, its repressiveness th to resolve the forms of disagreement that are void of violence [32, p. 29].

German researcher W. Ruf has identified the main tendencies of the state losing its monopoly on the use of violence and, accordingly, the privatization of violence. First, weak control of certain territories; second, decisive forms of citizens' security are expressed primarily in the rebellion against the central government and financed through the control of resource-rich territories and corresponding contracts with multinational corporations; new models of legitimacy are formed by inclusion / exclusion (the division of resources is through a system of «one's own - alien», especially if it is carried out on ethnic grounds; the main role is played by armies, because they have a functional hierarchical structure, recruiting young people to military groups and recruiting the method seeks to get rid of its poor position [33, p. 17].

Therefore, the privatization of violence is a factor in social mobility and social transformation. This allows one to speak of the privatization of violence as a complex structured social process: as a form of social self-organization in the face of weakening state power, as an instrument of struggle between different social groups and communities, as a means of material and economic enrichment. The statement of this reality allows us to consider privatized violence as an independent concept having a specific scope and content. It can be defined as a form of coercion by one group of people (one individual) against another group (individual) in order to obtain or maintain certain benefits and privileges, gain political, economic and any other domination. Forms of violence are divided into economic, social, political, ideological, physical and other [34, p. 135]. Integrative signs of violence in this context are active material and practical interaction, excellent social actors, complications in meeting their needs, realization of interests and goals.

Coercive means used by the state are mostly legitimate and implemented within the framework of the legislation in force in the country. Opposition forces often resort to privatized violence to gain power. Such actions by the opposition are illegal, although when the goal is achieved, the subject and the object of violence 
change places. The actions of the new ruling elite are declared legal and legitimate, while the previous one is outlawed.

Globalization is also accompanied by the systematic differentiation of the society, the source of which is economic and cultural integration, actualized by modern migration processes, the loss of control over the state border and territories by the state. This is accompanied by the impossibility of the government institutions to apply traditional methods of discipline-based control, and the state actually loses its monopoly on violence. There are objective attempts to concentrate resources to prevent these processes. It is a tendency to use a legal system that should regulate all social and personal relationships as necessary. However, it is precisely because of the intensification of differentiation processes that laws, regulations, orders and other regulations are either incapable of fully fulfilling a regulatory function, or because of their redundancy have a formal or even a formalized meaning.

Observations show that the manifestations of violence are conditioned by the willingness of the parties to the conflict to violence, their verbal confrontation. Such readiness is formed through the mediation of identification on the principle of «We - They», «Ours - Strangers». This serves as a basis for ethnic, religious, and political violence. Later, in the process of direct confrontation between the conflicting parties, the instigation of low instincts, namely fear, intimidation, self-preservation, and revenge, are the motivating motives of privatized violence.

One of the forms of privatized violence under such conditions is corporate violence, formed on the basis of the traditions, rules and regulations of the functioning of corporations, enterprises, labor collectives, which supplement the legal regulation of relations and, even, partially replace them. Employees knowingly execute certain orders and orders for fear of condemnation for violating corporate ethics. The component of corporate violence is privatized corporate security, which is to delegate the basic functions of employee safety, financial management, material resource conservation, and, especially in recent years, information security to corporations themselves. This is accompanied by a significant increase in the number of security and safety specialists, technological and technical equipment of their activities, gaining the right to use force to exercise their powers.

In today's societies, which are characterized by deep structural differentiation, the duration of the impact of «rational» violence is reduced, they are characterized by a tendency for permanent social transformations, which are expressed in outbreaks or mass irrational riots, protests, mass or single ones. The latter are expressed in the form of mass shootings or collective suicides. The state is not able to guarantee the safety of citizens in its totality. The privatization of violence involves the possibility for certain individuals or groups to commit state violence in certain territories or in certain groups on a private or quasi-private basis. In such circum- 
stances, paramilitary formations appear that perform the function of order control but are not funded by the state but by individuals or groups of persons to whom they are subordinate. They may have legitimate status, but they rarely acquire legitimacy. The form of privatized violence is also terrorism, which manifests itself both on the national borders of states and on the geopolitical space

The already mentioned $\mathrm{H}$. Wulf identifies two trends in the privatization of violence by engaging in struggles between different groups and communities during the period of social transformation of private paramilitary groups. The first is the privatization of «bottom-up» violence, in which agents of social change (unorganized armed forces) create a situation of insidious insecurity, act as a cause of chaotic, lawless situations, or even destroy state institutions, effectively taking responsibility for the loss of state monopoly [35, p. 36]. As U. Beck points out, such privatized violence confronts the authorities so much that even if the latter is based on strong consensus, it can easily be provoked by the provocation of small groups of determined-minded abusers (suicide bombers), and by the first subjects for whom world conflicts cultures offer thousands of reasons for putting the hightech world in the face of its own irreparable vulnerability [36, p. 106].

The second is «top-down», in which the privatization of violence is carried out by the authorities through outsourcing of traditional military and state functions to private companies $[28$, p. 36]. In the second case, two options for outsourcing can be distinguished: delegation of authority to either foreign (usually international) companies or domestic companies [35, p. 36]. The first option involves external interference in social transformation processes. This political decision is motivated by internal social factors. It allows a power that does not have sufficient military power to convert some of its own funds quickly enough without involving national armed forces. At the same time, in their activity, these companies do not respect the rights of civil rights and international humanitarian law, they use any forceful methods to protect their interests [37, p. 141].

The increase in demand for private military services is attributed to the massive demobilization of highly qualified military personnel from many countries as a result of the end of the Cold War. Their inability to adapt to new social conditions could threaten the social stability of a demilitarized society [37, p. 141]. The alternative, in the form of involving them in the activities of militaristic or paramilitary organizations, has, in fact, shaped the market for violence, both on a societal and international scale.

The second option reflects the dialectic of the struggle of the parties to social conflict and is a way to prevent «mythical» violence. During the period of approval of «mythical» violence in order to preserve the dominant «rational» power can involve sports and militaristic organizations. The said privatization of violence is intended, in our opinion, to give them the functions of direct physical violence, 
since such actions by the authorities cause the rise of mass protests and the unpopulated domination of «mythical» bloody violence. Therefore, the activity of state power is ambivalent. On the one hand, it loses its monopoly on the use of violence, delegating some of its powers to these organizations, and on the other, it supports the resources of violence against protesters

This trend actualizes the problem of changing the security strategy at the national and international levels. According to a domestic researcher on the problem of privatization of violence, $\mathrm{O}$. Poltorakov, transnational business (institutionalized MNCs and MNBs) essentially privatizes national states, the importance of the geoeconomic component of international security increases, the essential characteristics of the «arms market», which gradually turns into a state-centric, transformed (decentralized). The state has begun to perceive the private sector as a full-fledged equal partner in the field of national and state security, essential updating of citizens' needs for security services, which the state is unable to satisfy [38, p. 307-308].

It cannot be stated unequivocally that the partial transfer of powers to commit violence is temporary and is a one-off action aimed solely at reducing the level of aggression in society. Due to the destruction of classical mechanisms of control by the authorities over the practice of the exercise of legitimate violence, the state itself loses the possibility of sole control over the regulation of various types of violence, which leads to a blurring of the principles of responsibility for the actions of private actors of violence [39, p. 84]. A number of scholars, in particular G. Elwert, E. Eppler, D. Keen and S. Chojnacki, speak of the emergence of markets for violence as a social phenomenon. Such markets emerge as a result of the defect of state monopoly on the use of violence and in the presence of spaces open to violence, that is, social spaces in which violence is regulated not by traditional contexts or other mechanisms of organization and ordering, but by the ownership of goods and services is not voluntarily exchanged but appropriated forcibly [40, p. 201].

Existing turnover in the economic system of society is complemented by a violent method of obtaining goods. These processes tend to be long-lasting and are accompanied by the expansion of the space of violence, the replacement of the established principle of social relations by all other principles, and thus the loss of relevance of the factors that have led to social transformations. In the face of a prolonged lack of resources for the nationalization of violence in the government, that is, the return of a monopoly on violence, these organizations seek to legalize their right to privatized violence, formalize and even institutionalize.

Long-term economic development requires political stability, peace can only be achieved in the face of economic progress and prosperity. External shocks, such as sudden spikes in food prices, can cause tension and widespread protest within communities - especially those without adequate social protection networks - and even lead to conflict and even outright violence. In addition, widespread or increas- 
ing unemployment is undermining the world, encouraging the spread of criminal networks, gangs, and rebel groups. Sociological studies show that young people from countries affected by conflict call unemployment and idleness the most compelling reasons for joining such organizations. Against this background, governments need to step up their efforts to promote job creation and employment opportunities, including in finding ways to fund appropriate policies and programs. It is not by chance that the subjects of violence often appeal to justice, human values, even ideals. Thus, data from sociological studies on the identification of the level of tolerance of young people to deviations in society testify to the tolerant attitude of representatives of this age category to those deviant groups that can exist autonomously (alcoholics, vagrants, etc.), and readiness to reverse violence at immediate threat (bullies, bullying among students, etc.).

Particularly acute, the problem of violence, including privatization, has arisen in modern Ukrainian society. From this point of view, the dramatic self-determination of Ukrainian society with the priority vector of geopolitical integration, the signing and attempts to implement the Association Agreement with the European Union have resulted in fierce and violent resistance of certain political forces both domestically and externally, threatening socially. Democratization, privatization and market transformation, and today land reform, unemployment and mass impoverishment of the overwhelming majority of Ukrainians have generated claims by individuals and entire groups for special status, power and resources, in the course of which opponents neutralize, injure or eliminate their rivals. Socio-economic relations, at one of the poles of which there was an oligarchic state and at the other, a helpless atomized society, could not remain stable by definition. After all, post-Soviet society possessed electoral weapons to defend its interests in opposition to the oligarchs.

Separately, there is a problem that has arisen in our space recently. This is the problem of the influence of the creation of artificial identities on the actualization of the drivers of violent behavior. As the current practice of the Russo-Ukrainian war attests, aggressive propaganda through violent propaganda of artificial identities can lead to outbreaks of violent behavior

Today, there is no social group in Ukraine that identifies its interests with the state and the people, and the common state (national) interest arises from the set of private, divided interests of individuals and groups of people. We do not have a national bourgeoisie. Rather, a modern diaspora of new oligarchs with a corresponding environment emerged around them. The clan-oligarchic capitalism that currently prevails in Ukraine is perhaps the most inefficient model of economic, political, and cultural development since the North Korean Juche. Corruption is a solid one. All this speaks of the actual unmanageable state. For example, we have seen paramilitary organizations take over the functions of protecting the rights of 
non-law enforcement owners. However, in this case, the matrix fails at least twice. First, these organizations have assumed the functions of public authorities without formally delegating their powers to the latter. Second, paramilitary organizations grossly violate the Constitution of Ukraine because only state bodies have the right to use force [41, p. 24]

Maintaining the integrity of society, preventing chaos requires the active involvement of relevant social institutions, especially state institutions, which aim to protect the system, restore it, and prevent conflicts. Unfortunately, in a crisis of Ukrainian society, virtually no state institute fully fulfills its functions. Each of them is in its own way deformed, refined, weakened, disorganized. For example, failure of the functioning of social institutions, their weakening, a significant decrease in the effectiveness of their activities. Deformation of the work of state institutions continues throughout the years of independence. Numerous examples can be cited, when the Parliament and the President opposed virtually all the Presidents, and the confrontation between law enforcement. This defect has not been eradicated so far. Is this not a testament to the stiff confrontation between the SAP and NABU in recent years? [41, p. 23-24].

For the sake of objectivity, it should be said that some steps have been taken to reduce instability and violence in society and the state, and efforts have been made to strengthen state institutions. However, efforts to restore the vertical of power (for example, returning to the 1996 Constitution, strengthening the role of the President's Institute, forming a majority in parliament through the transition from faction to faction, influence of the executive branch on the judiciary, etc.) have become a concern in society.

But more importantly, in our society, the process of becoming legal statehood, the crystallization of new social strata, the manifestation of their social contours, and the formation of political identity are very slowly taking place. Therefore, there is no clear political representation of social groups in power structures, especially in parliament. It turns out to be a vicious circle: the blurring of the boundaries of social strata gives rise to a blur of social and political identities, and the blurring of the self-consciousness of groups gives rise to a loose political structure of a society consisting of political entities with vague programmatic goals and poorly expressed values. In the context of blurred boundaries of public communities, voting in the elections of the President, Parliament, local self-government bodies have become situational in nature and does not reflect the political structure of society. Such a situation is known by the famous sociologist M. Shulga as a manifestation of the failure of the social matrix [41]

Another feature of both parliamentarism and political life in Ukraine was that in all the years of independence, relations between the authorities and the opposition were characterized not by political rivalry, not by competitiveness, but by the 
Cold War. Each side fought the opposite for destruction. It is implied that such a situation was abnormal when in society the idea was asserted that the other party was not a rival but an enemy, not my compatriot, who wished good to his people, his homeland, although he saw a way to achieve it differently, his own, but the exiled saboteur, the bandit, the foreign agent, the «fifth column», which is not a political competition in the elections, but there is an ice slaughter [41, p. 59-61].

It is now extremely important politically and ideologically to ensure economic transformation in Ukraine and to prevent a situation where the problem of transition to a mixed economy is being sidelined, giving way to ensuring the stability of the existing status quo and trivial survival. This should be a coherent, energetic and sufficiently rigorous state policy, much firmer than in the period of normal development. It is the consolidation of the statehood of Ukraine that guarantees the need for economic transformation. In our search for a modern national idea, in the realities of the 21 st century, Ukraine, in our opinion, must proceed from the fact that it must form the basic spiritual and material foundations for the construction of modern Ukrainian institutions of state, law and civil society.

Conclusions. The problem of violence, although it invariably accompanies all phenomena and processes throughout the history of human civilization, is one of the most controversial and poorly researched topics in social science. The peculiarity of different approaches to the problem of privatized violence is the search for tools, a certain theoretical model that will exclude or regulate the manifestations of this social phenomenon at all levels of human practices. Analysis of the anthropological determinants of human aggressiveness shows that centuries of sociogenesis, a person's internal ability to contain his tendency to violence and aggression, is easily overcome by the influence of external factors, such as ideology. In addition, the sphere of human corporeality is now increasingly regulated through medicine, psychology, genetics, educational and manipulative technologies. If political violence is institutionalized, incorporated into the mechanism of action of society's values, embedded in the social structure by various methods, and transformed into an instrument of social order organization, primarily through coercion, stimulation and persuasion, then hidden violence, on the contrary, stimulates the increase of uncertainty and chaotic life of everyday life.

The anthropological component of privatized violence turns it into a phenomenon of social consciousness, which is an essential factor determining the process of cultural and historical development of society. The function of punishment exercised by the subjects of privatized violence to establish «social justice» is the modern equivalent of the institute of vengeance, which is based on a specific irrational understanding of people's perceptions of damages through revenge. The problem of privatized violence is one of the defining characteristics of the globalized world. The formation of new individual, collective, socially organized prin- 
ciples of tolerant existence is becoming an increasingly popular trend in the development of modern civilization. An alternative to violent practices should be the nonviolent path of further human development.

\section{REFERENCES}

1. Nort, D., Wallis, J. \& Waingast, B. (2017). Nasylstvo ta suspilni poriadky. Osnovni chynnyky, yaki vplynuly na khid istorii [Violence and Social Orders: A Conceptual Framework for Interpreting Recorded Human History] / per. z anhl. Taras Tsymbal. Kyiv: «Nash format», «Nezalezhnyi kulturolohichnyi zhurnal "I"» [in Ukrainian].

2. Agamben, G. (2011). Homo sacer. Chrezvychajnoe polozhenie [Homo Sacer: State of Exception]. Moskva : Izdatel'stvo «Evropa» [in Russian].

3. Agamben, G. (2011). Homo sacer. Suverennaja vlast' ' golaja zhizn' [Homo Sacer: Sovereign Power and Bare Life]. Moskva: Izdatel'stvo «Evropa» [in Russian].

4. Alvarez, A. C. \& Bachman, R. D. (2020). Violence: the enduring problem. Fourth Ed. Thousand Oaks: SAGE Publishing.

5. Christopher, M. N. \& Phillippi B. D. (2020). Archaeologies of violence and privilege. Albuquerque: University of New Mexico Press.

6. Derrida, J. (2002). Acts of religion / edited and with an introduction by Gil Anidjar. New York: Routledge.

7. Fanon, F. (2004). The wretched of the earth / translated from the French by Richard Philcox; introductions by Jean-Paul Sartre and Homi K. Bhabha. New York: Grove Press.

8. Frazer, E. \& Hutchings K. (2020). Violence and political theory. Cambridge, UK; Medford, MA: Polity.

9. Hayek, F. A. (2007). The Road to Serfdom: text and documents / edited by Bruce Caldwell. Chicago: University of Chicago Press.

10. Imbusch, P. (2002). Der Gewaltbegriff. Heitmeyer, W. \& Hagan, J.(Eds.). Internationales Handbuch der Gewaltforschung, S. 26-57. Wiesbaden: Westdeutscher Verlag.

11. Schmid, H. B. (2020). Evil in joint action: the ethics of hate and the sociology of original sin. Abingdon, Oxon; New York, NY: Routledge.

12. Sofsky, W. (1993). Die Ordnung des Terrors: Das Konzentrationslager. Frankfurt am Main: S. Fischer.

13. Sofsky,W. (1996). Traktat über die Gewalt. München: Fischer.

14. Staudigl, M. (2010). Násilie ako udalost' zmyslu a postihnutost'. Prolegomena k fenomenológii násilia. Náboženstvo a nihilizmus: z pohladu filozofie existencie a fenomenológie, S. 207-225. Bratislava Filozofický ústav SAV.

15. Staudigl, M. (2015). Phänomenologie der Gewalt. Cham: Springer.

16. Svendsen, L. Fr. H. (2008). A Philosophy of Fear. 2nd ed. London: Reaktion Book.

17. Svendsen, L. Fr. H. (2010). A Philosophy of Evil / Translated by Kerri A. Pierce. London: Dalkey Archive Press.

18. Zizek, S. (2008). Violence. New York: Picador. 
19. Sliusar, V. M. (2019). Problema nasyllia u filosofskykh rozvidkakh druhoi polovyny XX stolittia [The problem of violence in the philosophy of the second half of the twentieth century]. Visnyk Zhytomyrskoho derzhavnoho universytetu imeni Ivana Franka. Filosofski nauky - Bulletin of Ivan Franko Zhytomyr State University. Philosophical sciences, . 2(86), 51-60 [in Ukrainian].

20. Panfilov, O. Yu. (Ed.) (2013). Sotsialno-humanitarna sfera Ukrainy pered hlobalnymy vyklykamy suchasnosti. Monohrafiia [Social and humanitarian sphere of Ukraine in the face of global challenges of today. Monograph]. Kharkiv: Vydavnytstvo «Inzhek» [in Ukrainian].

21. Panfilov, O. Yu. (Ed.) (2019). Sotsialno-humanitarna sfera Ukrainy v suchasnykh dyskursakh: monohrafia [Social and humanitarian sphere of Ukraine in modern discourses: monograph]. Kharkiv: KhIF KNTEU, vydavets O. A. Miroshnychenko [in Ukrainian].

22. Poltorakov, O. Yu. (2019). Pryvatyzatsiia nasylstva: istoryko-sotsialna dynamika stanovlennia [Privatization of violence: historical and social dynamics of becoming]. Visnyk NTUU "KPI». Politolohiia. Sotsiolohiia. Pravo - Bulletin of NTUU "KPI". Politology. Sociology. Law, 3(43), 127-132 [in Ukrainian].

23. Sliusar, V. M. (2017). Nasyllia: sotsialno-filosofska pryroda [Violence: social and philosophical nature]. Zhytomyr: Vyd-vo Yevenok O. O. [in Ukrainian].

24. Trebin, M. P. (Ed.) (2013). Hromadianske suspilstvo: politychni ta sotsialno-pravovi problemy rozvytku: monohrafiia [Civil society: political and social and legal problems of development: a monograph] / H. Yu. Vasyliev, V. D. Vodnik, O. V. Volianska ta in. Kharkiv : Pravo [in Ukrainian].

25. Trebin, M. P. (Ed.) (2016). Pravova i politychna kultura ukrainskoho sotsiumu za umov modernizatsii polityko-pravovoho zhyttia: monohrafia [Legal and political culture of Ukrainian society in terms of modernization of political and legal life: a monograph] / [O. O. Bezruk, L. M. Herasina, I. V. Holovko ta in.]. Kharkiv: Pravo [in Ukrainian].

26. Trebin, M. P. (Ed.) (2019). Polityko-pravova mentalnist ukrainskoho sotsiumu v umovakh yevropeiskoi intehratsii : monohrafiia [Political and legal mentality of Ukrainian society in the context of European integration: monographs] / [O. O. Bezruk, V. S. Blikhar, L. M. Herasina ta in.]. Kharkiv : Pravo [in Ukrainian].

27. Toftul, M. H. (2016). Entsyklopedychnyi slovnyk z istorii ta teorii morali: slovnyk [Encyclopedic Dictionary of History and Theory of Morality: Dictionary]. Zhytomyr: Vyd. O. O. Yevenok [in Ukrainian].

28. Nort, D. (2000). Instytutsii, instytutsiina zmina ta funktsionuvannia ekonomiky [Institutions, Institute of Law and Functionality of the Economy]. Kyiv: Osnovy [in Ukrainian].

29. Eppler, E. (2002). Vom Gewaltmonopol zum Gewaltmarkt? Die Privatisierung und Kommerzialisierung der Gewalt. Frankfurt am Main: Suhrkamp Verlag.

30. Martinez, L. (1998). La Guerre civile en Algérie (1990-1998). Paris: Karthala. 
31. Poltorakov, A. Ju. (2009). Privatizacija nasilija: sociopoliticheskij kontekst. [Privatization of Violence: Sociopolitical Context]. Politika i obshhestvo - Politics and society, 10, 45-52 [in Russian].

32. Mair, S. (2002). Die Globalisierung privater Gewalt: Kriegsherren, Rebellen, Terroristen und organisierte Kriminalität. Berlin: SWP-Studien.

33. Ruf, W. (1999). Zur Privatisierung von Gewalt. Luedtke, R.-M., Strutynski, P. (Hrsg.) Pazifismus, Politik und Widerstand. Analysen und Strategien der Friedensbewegung, S. 16-26. Kassel: Jenior Verlag.

34. Sitarov, V. A. (2005). Nasilie i nenasilie [Violence and Non-Violence]. Znanie. Ponimanie. Umenie - Knowledge. Understanding. Skill, 1, 135-139 [in Russian].

35. Wulf, H. (2007). Privatizing and internationalizing violence. The Economics of Peace and Security Journal, 2(1), 35-40.

36. Bek, U. (2011). Vlada i kontrvlada u dobu hlobalizatsii. Nova svitova politychna ekonomiia [Power and counter power in the age of globalization. The New World Political Economy]. Kyyiv: NikaTsentr [in Ukrainian].

37. Tseluiko, V. O. (2006). Pryvatni viiskovi kompanii i pryvatyzatsiia funktsii derzhavy u voiennii sferi [Private military companies and privatization of functions of the state in the military sphere]. Stratehichna panorama-Strategic panorama, 1, 139-143 [in Ukrainian].

38. Poltorakov, O. Yu. (2017). «Pryvatyzatsiia nasylstva»: heostratehichni konteksty tinovoi ekonomiky [«Privatization of Violence»: Geostrategic Contexts of the Shadow Economy]. Tinova ekonomika: svitovi tendentsii ta ukrainski realii: materialy mizhvidomchoi nauk.-prakt. konf (Kyiv, 23 cherv. 2017 r.) - Shadow economy: world trends and Ukrainian realities: materials of the interdepartmental scientific and practical conference (Kyiv, June 23, 2017) / redkol.: V. V. Cherniei, S. S. Cherniavskyi, V. I. Shakunta in. Kyiv: Nats. akad. vnutr. Sprav, 306-308 [in Ukrainian].

39. Kravchenko, V. Yu. (2014). Osoblyvosti pryvatyzatsii politychnoho nasyllia v konteksti transformatsii lehitymnosti derzhavnykh instytutiv [Features of privatization of political violence in the context of transformation of legitimacy of state institutions]. Visnyk Dnipropetrovskoho universytetu - Bulletin of Dnipropetrovsk University, 22(24), 79-87 [in Ukrainian].

40. Chojnacki, S. (2004). Gewaltakteure und Gewaltmärkte: Wandelder Kriegsformen? Der Bürger im Staat, 54(4), 197-204.

41. Shulha, M. O. (2018). Zbii sotsialnoi matrytsi [Social Matrix Failure]. Kyiv: Instytut sotsiolohii NAN Ukrainy [in Ukrainian].

Козловець Микола Адамович, доктор філософських наук, професор, професор кафедри філософії та політології, Житомирський державний університет імені Івана Франка, Україна

Слюсар Вадим Миколайович, доктор філософських наук, доцент, професор кафедри філософії та політології, Житомирський державний університет імені Івана Франка, Україна 


\section{ПРИВАТИЗОВАНЕ НАСИЛЛЯ: СУТНІСТЬ ТА ВИДИ ЙОГО ЗДІЙСНЕННЯ В СУЧАСНОМУ СВІТІ}

Постановка проблеми. Насилля, незважаючи на зміну його форм та інструментальне призначення, неодмінно супроводжує всі явища і прочеси упродовж всієї історій людськоӥ ичивілізацій. Легітимація права окремих людей або сочіальних груп посягати на здоров'я, свободу та іниі цінності людського жсття в усі часи надзвичайно дорого обходилась людству. Однак иіна насилля у добу стрімкого розвитку науки, техніки і технологій надзвичайно зростас. Проблема приватизованого насилля с однісю з визначальних характеристик глобалізованого світу. Тим самим актуалізусться наукова концептуалізація иісї проблематики, пов язаної з політологічним аналізом сутності насилля загалом і приватизованого зокрема, змістом і видами його прояву в сучасному світі.

Аналіз останніх досліджень і публікацій. У науковій літературі проблема насилля досліджуеться як у предметному полі політичної науки (Дж. Агамбен, Ф. фон Гаєк, К. Шлегель, А. Дмитрієв, І. Залисін, С. Кузіна), пак і у взаємозв'язку з філософськими (Ж. Дерріда, С. Жижек, М Штаудігл), психологічними (Ф. Фанон), етичними (Л. Свендсен), мас-медійними (Г. Енценсбергер), культурологічними (В. Софський) та іниими науковими розвідками. Дослідниками були проаналізовані структурне насилля у контексті соціальної справедливості, виправдання державной монополій на насилля та використання конкретних засобів сочіальних змін, виявлення різних форм насилля з акиентом на проблемі індивідуального, осмислення маситабності насилля. Різноманітні концептуальні інтерпретації проблеми насилля у політологічному аспекті зустрічаємо у прачях й вітчизняних науковців: В. Бебика, Д. Бойка, С. Головатого, С. Головахи, В. Горбатенка, М. Михальченка, В. Кравченка, В. Кременя, В. Остроухова, О. Панфілова, О. Полторакова, О. Рудакевича, Ф. Рудича, В. Слюсаря, В. Ткаченка, $М$ Требіна, В. Целуйка, М. Шульги та ін. У той же час проблема насилля, насамперед приватизованого, залииається однією з найбільи дискусійних і малодосліджених у суспільствознавстві.

Метою статті є дослідження на основі аналізу історичного досвіду і сучасной практики сочіальної природи та причин посилення приватизованих форм насилля, чинників і механізмів його здійснення в сучасному світі.

Виклад основного матеріалу досліджсеня з обггрунтуванням отриманих наукових результатів. Концептуалізовано поняття «приватизоване насилля» у контексті теоретичних і загальнокультурних досліджень насилля, що дозволило виокремити його із загального понятійного ряду "соціальне насилля» $і$ визначити як об 'єктивний чинник суспільного розвитку, а також систематизувати його за різними підставами. Констатовано, шо у проявах насилля й агресії виявляеться значення біологічних і психологічних якостей, але визначальним є сочіальний фактор. Антропологічна складова приватизованого насилля перетворює його у феномен суспільной свідомості, який виступає істотним фактором, ио визначає процес культурно-історичного розвитку суспільства. Якио політичне насилля інститу- 
ціоналізоване, включене у механізм діӥ цінностей суспільства, вбудоване у соціальну структуру різними методами і трансформується в інструмент організації суспільного порядку насамперед через примус, стимулювання і переконання, то приховане насилля, навпаки, стимулюе зростання невизначеності й хаотичності повсякденного життя.

Особливу увагу звернено на вплив глобалізаційних прочесів на насилля, утвердження й посилення його непрямих, приватизованих форм. Наводяться причини виникнення приватизованого насилля і чинники, які зумовлюють його посилення в сучасних умовах. Розглядаються сочіальні групи, які вдаються до приватизованого насилля, моделі комунікативной поведінки й стилі управління в конфліктній і постконфліктній ситуаціях. Розкриваються особливості політичной культури трансформаційного украӥнського суспільства, які впливають на посилення соціально-політичної напруженості та мотивауію щуодо приватизованих форм насилля.

Висновки з цього досліджсеня й перспективи подальших розвідок у цьому напря.нку. Зроблено висновок про сочіальну зумовленість приватизованого насилля па доцільність формування культури ненасилля, толерантності і згоди в сучасних умовах. Поиуки иляхів формування нових індивідуальних, колективних, сочіально-організованих принцииів толерантного існування стає дедалі більие затребуваним напрямом розвитку сучасної циивілізації. Альтернативою насильницьким практикам має стати ненасильницький илях подальиого розвитку людства.

Ключові слова: насилля, ненасилля, феноменологія насилля, сочіальне ненасилля, приватизоване насилля, справедливе насилля, суспільство, суспільний порядок.

Козловец Николай Адамович, доктор философских наук, профессор, профессор кафедры философии и политологии Житомирского государственного университета имени Ивана Франко, Украина

Слюсар Вадим Николаевич, доктор философских наук, доцент, профессор кафедры философии и политологии Житомирского государственного университета имени Ивана Франко, Украина

\section{ПРИВАТИЗИРОВАННОЕ НАСИЛИЕ: СУЩНОСТЬ И ВИДЫ ЕГО ОСУЩЕСТВЛЕНИЯ В СОВРЕМЕННОМ МИРЕ}

В статье рассмотрено социальную природу насилия и его формы, особенности проявления и осуцествления. Концептуализовано понятие «приватизированное насилие» в контексте теоретических и общекультурных исследований насилия, что позволило выделить его из общего понятийного ряда «сочиальное насилие» и определить как объективный фактор общественного развития, а также систематизировать его по разным основаниям. Приводятся причины возникновения приватизированного насилия и факторы, которые обусловливают его усиление в современ- 
ных условиях. На основе анализа исторического опыта и современной практики исследовано содержание и спещифику проявления приватизированного насилия, механизмы и факторы его осуцествления в современном мире. Особое внимание обращено на влияние глобализационных процессов на насилие, утверждение и усиление его косвенных, приватизированных форм. В проявлениях насилия и агрессии констатируется значение биологических и психологических качеств, но определяющим признается сочиальный фактор. Раскрываются особенности политической культуры трансформачионного украинского общества, влияющие на усиление соииально-политической напряженности и мотивацию в отночении приватизированных форм насилия. Рассматриваются соииальные группы, которые прибегают $\kappa$ приватизированному насилию и модели коммуникативного поведения, и стили управления в конфликтной и постконфликтной ситуации. Сделан вывод о сочиальной обусловленности приватизированного насилия и целесообразности формирования культуры ненасилия, толерантности и согласия в современных условиях.

Ключевые слова: насилие, ненасилие, феноменология насилия, сочиальное насилие, приватизированное насилие, справедливое насилие, общество, общественный порядок. 